\title{
STUDYING AGACIRO. MOVING BEYOND WILSONIAN INTERVENTIONIST KNOWLEDGE PRODUCTION ON RWANDA
}

\author{
Dr. Olivia Umurerwa Rutazibwa (University of Portsmouth)*
}

Twenty years after the end of the Rwandan genocide, knowledge production on the small country of a thousand hills remains a clamorous battle ground of post-and decolonial power and influence. In this essay I critically engage with the knowledge production on Rwanda in the West by conceptualising it as a Wilsonian intervention in the post-colony: paternalistically well-intended at the service of the peace, democracy and free trade liberal triad, while at the same time silencing, self-contradictory and potentially counterproductive. The Wilsonian interventionist form of knowledge production is coated in a language of critical engagement and care. At the same time it is and allows for a continuous external engagement in view of this Wilsonian triad (Acuto 2008, 463) - a highly particularist view on the good life, cast in universal terms.

As a former journalist and a researcher from the Belgian Rwandan diaspora and building on a decolonial research strategy, in this essay I reflect on potentially different avenues to produce and consume knowledge on the country. I do this by discussing the challenges and creative opportunities of a recently started research project on Agaciro (self-worth): a philosophy and public policy in post-genocide Rwanda rooted in its precolonial past, centred on the ideals of self-determination, dignity and self-reliance. Rather than inscribing itself firmly into the canon that aims at informing on Rwanda, this research project seeks to contribute to a different mode of imagining, studying and enacting sovereignty in today's academic and political world, both permeated by the hegemonic principle of the responsibility to protect (R2P).

\section{INTRODUCTION: CONCEPTUALISING THE MAINSTREAM CANON ON}

\section{RWANDA}

Commemorations and anniversaries tend to be ideal sites to investigate the quality and effects of our knowledge production. In the days leading up to the start of the 100 commemoration days on April 7th 2014, clear attempts were made to dig deeper into Rwanda's past and present. The mainstream media were inundated with a five minutes avalanche of news and background stories of a nevertheless silenced country.

Mainstream, in this context, refers to a canon, a body of knowledge rather than individual pieces of work or authors. It more specifically refers to the collection of the majority of the best known, most accessible, most read accounts on Rwanda in the media and the scholarship. Often times, the glue between the two - a common feature in the knowledge production on Africa - are the many Western and internationally financed NGO and aid workers that provide information from the field. For many Western journalists, as well as some scholars, they tend to be the first point of contact, while on

\footnotetext{
* Contact details: olivia.rutazibwa@port.ac.uk School of Languages and Area Studies, University of Portsmouth, Park Building King Henry I Street, Portsmouth PO1 2DZ, United Kingdom, 00442392846154

Olivia Umurerwa Rutazibwa is a lecturer in International Development and European Studies at the University of Portsmouth, UK. Her research focuses on critical, post- and decolonial approaches to (humanitarian) interventions and sovereignty, democracy promotion and (EU) foreign policies in sub Saharan Africa. She has a PhD in Political Sciences from Ghent University, Belgium and is an alumna of the European University Institute in Florence, Italy and is a former journalist and Africa desk editor at the Brussels based magazine on international affairs, MO*.
} 
location or behind their desks. Those same journalists consult the existing scholarship on Rwanda, which has, especially in the case of Belgium, often close relations with the NGO world, when crafting the angle of their chosen storyline. It turn, these scholars are invited or offer to fill the op-ed pages of those newspapers or give commentary on radio or television.

Given the yearly commemorations, and the attention and scholarship afforded to Rwanda - not in the least in its former colonizer, Belgium - how then is the country silenced? Unlike many other subSaharan African countries in the Western mainstream, Rwanda is usually not silenced in the sense of ignored. Indeed, aside from the genocide in 1994, the country's perceived lack of civil and political freedoms, its involvement in the conflict and human suffering in the neighbouring Democratic Republic of Congo (DRC) and the subsequent recurrent threats by Western donors to cut aid, ensure a regular appearance of Rwanda in the Western news cycles.

Rwanda is silenced however, in the sense that when attempts are made to storify its present, most of us seem incapable of transcending the Hutu/Tutsi, rural/urban, men/women, rich/poor, dictatorautocrat/democrat, pro/contra FPR regime categories (Hintjens 2014). That these categories are used to initially approach a complex reality is in itself not problematic. However, when they operate as blinds, incapacitating us to see and convey the complexities and developments in the making on the ground, they are a silencing device.

Rwanda is silenced, in the sense that the experts are invariably of Western origin - even if they have not been allowed into the country in the last decade or more. When Rwandan sources are included usually as informants rather than authors - they tend to be either cast as victims, corroborating the experts' analysis, or as partisans, too closely linked to the current regime to be trusted for objective information.

All in all, the silencing that befalls Rwanda amounts to a binary presentation of a complex place - the preferred format usually a variation of 'the country is progressing but...'. The most damaging aspect of our silenced Rwanda stories is that they do not in the main serve the purpose of knowledge production and dissemination per se. They explicitly or implicitly follow the logic of a judgement call on its performance towards the Wilsonian triad, the contemporary Western-led dominant view on the good life, thus perpetuating the image of the place as needing external presence and interference. As such, apart from the actual relations with Rwanda, our Western knowledge production is an integral part of what I would call a Wilsonian intervention.

\section{A WILSONIAN INTERVENTION}

It is a people's treaty, that accomplishes by a great sweep of practical justice the liberation of men who never could have liberated themselves, and the power of the most powerful nations has been devoted not to their aggrandizement but to the liberation of people whom they could have put under their control if they had chosen to do so. Not one foot of territory is demanded by the conquerors, not one single item of submission to their authority is demanded by them.' (Wilson 1919)

Why a Wilsonian intervention? I contend that the concept of a Wilsonian intervention is a useful analytical device to conceptualise both the 'good' and the 'bad' in what we try to achieve when writing about Rwanda.

The morally and ethically driven nature of our endeavours at the service of truth, democracy and freedom are premised on an isomorphic, copy/paste conception of the good life (i.c. electoral liberal market democracy $)^{1}$, while at the same time being heavily soaked in a worldview in which some peoples' equality can only be projected in the future after a process of education, capacity building 
and awareness-raising on how to reach the good life. Additionally, Rwanda is an interesting case, because the tragic history of the genocide and the relative absence of the international community and the Rwandan push back against the - at best - classic paternalist good-will in the north-south development encounter, tend to constantly disturb and denaturalise our ${ }^{2}$ mission civilisatrice. It also explains in part our need to vilify, delegitimize or partially silence certain accounts on Rwanda. In general historiography, Woodrow Wilson, President of the USA during WWI and former President and scholar of Princeton University, is portrayed as a beacon of peace in turbulent times. He is known as the advocate for international rules amongst nations in his relentless efforts to rally the world and his fellow countrymen around the idea of the League of Nations, international free trade and free use of the seas. Additionally, he has been celebrated for his defence of both the right to democratic rule 'making the world safe for democracy' - and the principle of self-determination, in his own words: 'for all' (Wilson 1917b, Ambrosius 2008). He got a Nobel Peace Prize out of it and was invoked by many future freedom and independence fighters. For fundamentally - and not just in passing alternative accounts on the man and his ideas one can consider John M. Hobson's seminal book The Eurocentric Conception of World Politics (2012) or African American scholarship like that of Errol Henderson (2007). They focus on the racism and imperialist paternalism and what that means to IR scholarship in general.

Critically invoking Wilson to reflect on our knowledge production on Rwanda is it allows for highlighting the fundamental contradictions and problematics in our contemporary moral diplomacy and the scholarship that goes with it. It highlights a genuine care for peace, democracy and selfdetermination on the one hand; on the other, an incapacity to respect that same right to democratic rule and self-determination from the moment that the outcome deviates, or might deviate from the specific copy/paste script as we know it, thus both perpetuating and legitimizing external interference, actively trampling the space for self-determination.

Consider the following passage in Wilson's speech on the League of Nation Treaty in 1919: 'Great Britain obliged South Africa to submit to her sovereignty, but she immediately after that felt that it was convenient and right to hand the whole self-government of that colony over to the very men whom she had beaten. The representatives of South Africa in Paris were two of the most distinguished generals of the Boer Army, two of the realest men l ever met, two men that could talk sober counsel and wise advice, along with the best statesmen in Europe. To exclude Gen. Botha and Gen. Smuts from the right to stand up in the parliament of the world and say something concerning the affairs of mankind would be absurd. (...) You will see that international law is revolutionized by putting morals into it.' (Wilson 1919)

Not unlike Wilson, who invokes the sovereign rights of the white South African elites while at the same time clamorously silencing the majority of the peoples in that same country, we seem to be invoking the right principles for the advancement of human kind, while at the same time unconsciously making large parts of this same human kind invisible, and thus excluded from these rights in the present by projecting their rights - as opposed to Wilson, to whom the non-Western peoples seemed literally invisible - in the future.

Two crucial problematics ensue that prevent us from seeing them materializing in the present and any foreseeable future. Firstly, all the while employing the universal language of all and all of human kind, all throughout history, we have systematically managed to exclude peoples from the enjoyment of these rights. In Wilson's time these were the non-white peoples on the basis of their biological and civilizational inferiority. Today, ideas of biological or racial inferiority have lost their legitimacy in public discourse. Strangely enough it often is the same people - both ethnic minorities and undocumented migrants in the west and peoples in their home countries in the Global South - that 
are somehow silenced. While we do not openly profess their biological inferiority, both right-wing hardliners and left-wing liberals in Europe today seem to share - in different degrees - a sentiment of the silenced peoples' cultural inferiority, discernable in the discourses on integration and assimilation (at home) and development and capacity-building (abroad).

The content of that benign transformation of the other is the object of the second problematic. Not so much the content itself ${ }^{3}$ as the degree of detail in which they are defined, the place of origin of this defining practice and the level of freedom and agency to accept or reject this particularist version of the universally projected rights, makes the enjoyment of these rights of self-government and democracy in the present dependent upon not just the acceptance of the particularist Western understanding, but also one's capacity to enforce and guarantee them. This highlights the problematic and contradictory circular reasoning in the Wilsonian intervention.

Similar to Wilson (even though he was at best ambiguous on the right to self-determination for the 'non-civilised' peoples) we do not come back on this right openly, but project its enjoyment into the future after being capacity-built, educated, trained into our brand of democracy. Similarly to Wilson we seem incapable of dealing with difference seriously or peacefully, other than projecting it as a hierarchized site of plurality to be assimilated in the future, obliterated in the past, belittled, vilified, mistrusted or criminalised in the present. In policy terms, a similar tendency is discernible in the current debates on the Responsibility to Protect (R2P), where we see a consolidation of the shift of sovereignty and self-determination as a capacity rather than a right (e.g. Chandler 2010; Mamdani 2010). ${ }^{4}$ In our scholarship it manifests itself in a generally accepted consensus that we can mostly limit the debate on R2P to issues of implementation (Orchard 2012); in the specific case of Rwanda it manifests itself most clearly through the unspoken judgement rationale that seems to permeate our knowledge production on Rwanda in view of the Wilsonian good life.

\section{HOW TO WRITE ABOUT RWANDA? SOME DECOLONIAL SUGGESTIONS}

How then to write about Rwanda? A first important assertion is that there is not one way to truthfully write about Rwanda. A conscious pluralisation of authors and stories seems the way forward as a matter of urgency at this moment. Secondly, it is important to underline that a constructive critical approach to knowledge production on a place like Rwanda, or other countries and peoples far away, does not entail an incitement to Western (self)censorship. On the contrary. It is in a way a call to do more and better. Next to the need to pluralise authors and stories, which entails a more conscious engagement with our positionality and limited legitimacy at times, a critical approach to knowledge production is an invitation to also pluralise the rationales for our knowledge production. How can we move beyond knowledge production that first and foremost serves the judgement rationale, even if formulated in a language of objectivity? Is it still critical if we forsake this primary, often implicit goal, and how can that produced knowledge still contribute to the good life without it constituting a Wilsonian intervention?

By way of illustration I will elaborate shortly on one such possible alternative to the current mainstream knowledge production: decoloniality as a research strategy. Subsequently the text will move on to my recently started study of the philosophy and public policy of Agaciro in Rwanda and reflect on the challenges and opportunities it raises in terms of the decolonial knowledge production aims put forward here. 
Decoloniality as a research strategy in this context builds on, or is part of the broader family of postcolonial approaches to IR (Kapoor 2008; Ferguson 2007, 1990; Doty 1996; Baaz 2005). Initially articulated by Latin-American cultural studies scholars like Escobar, Mignolo and Quijano ${ }^{5}$, the decolonial approach, amongst others, firstly denounces the silencing of non-Western peoples and their experiences and seek to rectify what are seen as myths and myopia in mainstream IR. Examples of these myths range from the origins of wealth accumulation in the West, to the striking absence of issues of racism (Henderson 2007; Vitalis 2000) and atrocities (Muppidi 2012) in mainstream IR knowledge production. Secondly, decoloniality is explicit about its search for fundamental alternatives as an integral part of the knowledge production mandate.

In IR, Sabaratnam (2011) for instance, makes a typology of six decolonizing strategies, which I synthesize here - also building on other insights elsewhere in the literature (Gruffydd Jones 2006; Seth 2013 ; Scott 1999) - into the following three: de-mythology, de-silence and anti-colonial strategies. De-mythology refers to a need to reframe and add to existing mainstream arguments in the scholarship to contribute to the rectification of the Western-centric bias in mainstream knowledge-production about the world. Secondly, de-silence seeks to insert (non-Western) marginalized epistemologies and experiences as subjects of the knowledge production and theory formation. A third strategy is about anti-coloniality: going beyond the mere post-colonial denunciation of Western-centric myths and silencing practices by actively putting the postcolonial insights at the service of knowledge production that does not reinforce or perpetuate the societal status quo of oppression and inequality but allows for the imagination of alternatives.

As such a decolonial research strategy transcends the systematic introduction of colonialism as a (historical) object of research in IR. In this approach, the historical advent of colonialism, is only one of the ways in which to study extreme power inequality, in whatever context - domestically or internationally. In the context of IR it is an approach that openly focuses on extreme power inequalities to study and understand our current global social and political realities.

\section{\#AgACIRO. Adding to OUR KNOWLEDGE ON SELF-DETERMINATION, SOVEREIGNTY AND AUTONOMY}

The first time I came across Agaciro was in a 9 minutes short film on youtube by Annette Uwizeye (2011), commissioned for the Rwanda Day in Chicago in 2011. The mini-documentary showcases a future oriented and rallying perspective on what Agaciro is to mean for the viewers. Next to a collection of images that highlight the beauty of its rural landscapes, its traditional and contemporary crafts, fashion and arts as well as the modernism, dynamism and cleanness of its capital city, the short documentary film structures testimonials in English and Kinyarwanda of Rwandan artists, a journalist, clergyman, student, diaspora returnee, construction worker, rural dweller, and a resident of South Sudan, around two central statements on what Agaciro stands for. The first one contends that 'Agaciro is the backbone of Rwanda's history and the backbone of its prosperous future' (Uwizeye 2011, 0'45"). The testimonies refer to the principle of Agaciro as firmly rooted in Rwanda's precolonial past and evoke an understanding of the concept as related to having or losing dignity and a clear sense of right and wrong, to be passed on amongst each other. Someone loses his or her dignity once they engage in activities that violate ones humanity. The second statement reads that 'Agaciro is understanding that we are agents of our own change.' (2' 04 ") Successfully dealing with the horrors of the genocide is linked to the customised, tailored approach that was chosen in Rwanda, 
which builds on values and practices from the past. Additionally, the endless opportunities on offer in Rwanda for women and people from the diaspora are mentioned, as well as the solid and visionary leadership of the government as it is seen to have resulted in visible and effective programs in the city (relentless building works) and in the rural areas (e.g. the one-cow-per-family program, community health insurance, solid rooftops on all houses, ...) and all-round rapid economic growth. Rwandan soldiers are commended by a resident of South Sudan for the fact that they are very generous and disciplined, but most of all because they would always refer to themselves as Rwandans, even when asked what ethnic group they belong to.

The film ends with excerpts of a speech by President Paul Kagame on what Agaciro stands for: '...our people know what is good for them. We must endeavour to show it. We must be seen to be doing things that prove that. So Agaciro is simply central to everything we are doing for our development, that pride, that belief in ourselves, that being who we are and who we should be, and trying to be the best that we can be.'(7'54" - 8'17')

After that first digital encounter with Agaciro as a philosophy, I came across its more concretised, enacted version through campaigns and advertisement for the public policy of the Agaciro Development Fund. The idea is understood by most as born from a resentment of the donor community's intermittent threats to cut its funding in Rwanda. Building on the self-reliance elements in the Agaciro philosophy, in 2011 the government launched the idea of a sovereign fund, fuelled by its citizens' voluntary donations. In August 2012 the Agaciro Development Fund campaign was officially launched. The aim is to work towards a situation in which the country, for now still operating on a budget funded by international donors for about $40 \%$, would be donor-independent in the foreseeable future.

At the end of December 2013 I travelled to the Rwandan capital to conduct some preliminary interviews to see if Agaciro as a philosophy and public policy was viable as a research topic to study alternative ways to conceptualise sovereignty and post-conflict state building. The short film had mentioned Agaciro as the new buzzword in the hills, and my stay in Kigali confirmed that it was indeed a word that needed little explanation. Apart from the different formal and informal conversations, looking around me, I would see signs of it: a big front window sticker on a privately operated bus service reading www.agaciro.com (a blank webpage) or on a footrest of one of the many motor-taxi's, the word Agaciro sprayed against the background of the Rastafarian colours. One of my respondents, a private sector returnee from the US, mentioned that the daily talks about Agaciro as a general attitude in life became so prevalent in the office ${ }^{7}$ that they both jokingly and ironically shortened its constant invocation to '\#(Hashtag)Agaciro'. ${ }^{8}$

Next to several informal conversations, I ended up conducting eight formal open interviews of about an hour with a historian, a political scientist, the Agaciro Fund team at the Ministry of Finance, an artist, a retired civil servant in service during colonial times, a private creative business returnee, a retired Rwandan diplomat and a civil servant. The aim was not to have a representative sample of the Rwandan population, as the study is not designed to research the reach or the effect of Agaciro as a philosophy and public policy. I am first and foremost interested in how Agaciro is being conceptualised and enacted by its main proponents, i.e. the government and (urban) elites, and the variations in its meaning and whether this shifts over time and/or according to actors, audience and purpose. Secondly, given my interest in reconceptualising self-determination and sovereignty against the background of the shifted meaning of sovereignty through the hegemonic discourses on R2P, I also look at how and the extent to which Agaciro is defined as an inward-looking philosophy or a definition of a self as posited first and foremost against the outside other. 
The preliminary interviews show a range of different meanings and enactments of Agaciro, constantly shifting appropriations and interpretations, and a simultaneous inward and outward looking definition around a colonial past and a dependency present of the Agaciro self. One civil servant summarised Agaciro as 'at times outward oriented (sovereignty, autonomy), inward (legitimate expectation of a new social contract, cf. poverty alleviation policies with universal health care, education etc...) and individual (a newly found self-worth identity linked to pride in the future that is being built today)' (personal communication, August 1, 2014). In the future, the idea is to systematically observe selected sources of Agaciro manifestations over a certain period of time to allow for a thick description of the phenomenon. The aim is eventually to feed it back to an alternative conceptualisation of what sovereignty and good life can look like, and its different implications for our theorizing, before we dismiss it all together in our Western-led international academic and political conversation on R2P.

\section{CONCLUSION}

How does this particular research on Agaciro attempt to transcend the Wilsonian interventionist double problematic? First of all, as was mentioned before, by explicitly projecting its rationale as a feed-back onto theorizing on general issues of interest in IR like sovereignty and self-determination within the discussions on R2P and interventions. Secondly, the feeding back allows for a denaturalisation of the need for external intervention to reach the good life, as well as firmly inscribing alternative, so far, silenced philosophies and enactments in the universal discussion on the good life.

The more 'Wilsonian' option would have been to research Agaciro on its veracity, on the role of the government and the extent to which the philosophy and ensuing policies are forced upon or freely chosen by people, whether it helps put the country back on its feet or not. The point here is not that these research questions are not valid or even desirable. The choice made here potentially fills a gap in the existing IR scholarship where there is a structural silencing of philosophies, experiences and voices from the Global South in theorizing. This does not preclude the usefulness of the material of this Agaciro research for the local context. The critique of the Wilsonian intervention raises the question of who might be best positioned to apply it in such way. For myself, even though I am a Rwandan enjoying at times easier access, but I do not live in the country, have limited lived understanding of the society as a whole and lack the necessary language skills. I am confident that there are those much better positioned to use research on Agaciro in a problem solving sense for the local context.

It is therefore clear that there is a limit to the desilencing that one can engage in from a Western positionality when writing about a non-Western context, even when a member of the diaspora. Any decolonial research design therefore needs to be carefully tailored with these limitations in mind and remedy where possible. Systematically and structurally investing in local equal research partnerships and collaborations is but one concrete way to go about it.

The research as proposed here can be seen to limitedly contribute to the decolonial call to demythologize - by fundamentally challenging the inescapability of foreign interference in defining and aspiring the good life, so central in our thinking about the global. When it comes to anticoloniality in the sense of critically engaging with power inequality and producing knowledge that allows for imagining alternatives to the status quo, we are confronted with some outstanding challenges that are particularly relevant to the case of Rwanda. One of the main features of our story- 
telling - through journalism and scholarship - on Rwanda, is that it is implicitly or explicitly projected in the binary of pro or contra the actual political elite (seen as Tutsi dominated), government (run by the FPR) or president (Paul Kagame). Even if one consciously decides not to put such questions central in research design, it is an implicit calculation, awareness that seeps in every stage of the research process. In the case of this Agaciro research project, one can, for instance, not but consider the origin and reason behind the commissioned short-film that sparked the initial interest in this research project; or the position and or occupation of the selected respondents and the fact that Agaciro is a very much government led philosophy and policy, even if it finds its roots in Rwanda's cultural past. There are no clear cut answers to this, but it is, like for all research projects, nevertheless imperative that one makes fitting and self-reflexive choices. In my case, it helps that the research is not devised to answer the question on the legitimacy and effectiveness of Agaciro per se. Having said this, the third leg of the decolonial research strategy, anti-coloniality, nevertheless entails an imperative to push beyond these pragmatic research choices and reflect on how they contribute to existing power inequalities and oppression. The call, embedded in the judgemental rationale in our knowledge production on Rwanda, to critically engage with local power structures can therefore not be lightly brushed off in a decolonial attempt to transcend the Wilsonian interventionist critique. At the same time, next to the local power inequalities, there is also the West/non-West structural power distribution at a global or bilateral level. Facing these dual or multiple sources of power inequality, I would argue that it is important to consider one's positionality when seeking to be critical in the decolonial sense as well as mindful of the Wilsonian interventionist critique. When writing from a Western positionality I would be inclined to prioritise the global inequality struggle in the research design.

This does not dismiss the possibility of international solidarity though. The critiques presented in this essay can be read as an open call to further reflect on alternative ways in which we can embody international solidarity without having to automatically resort to what I have coined a Wilsonian intervention: often well-intended, but ultimately counter-productive and silencing. One first concrete step would be to take up the call to pluralise the story tellers, not just as respondents or datacollectors, but fundamental shapers of theory formation and conceptualisation, more seriously and as a matter of urgency. A second way of reflecting on alternative solidarity is what I have elsewhere (Rutazibwa 2013) called ethical retreat: a form of retreat that is not to be equated to disinterest or disengagement, but a creating of space for the people concerned at the local level, while at the same time, as externals, recommit to the first do no harm principles when devising domestic and international policies. Ethical retreat applied to knowledge production on Rwanda therefore by no means entails ceasing or delegitimizing micro analysis and field research from a Western positionality. It is rather an invitation to revalorize the experiences and epistemologies of the places we are privileged enough to engage with intellectually, while being mindful of the ways in which our judgement-oriented knowledge production, as it has in the past, fractures or stalls the good life, however defined, in Rwanda. 


\section{REFERENCES}

Acuto, M. 2008. "Wilson Victorious? Understanding Democracy Promotion in the Midst of a 'Backlash'." Alternatives: Global, Local, Political 33: 461-480.

Ambrosius, L.E. 2008. "Democracy, Peace, and World Order." In Reconsidering Woodrow Wilson: Progressivism, Internationalism, War and Peace, edited by J.M. Cooper, 225-252. Washington D.C.: Woodrow Wilson Center Press, Baltimore: The John Hopkins University Press.

Baaz, M. 2005. The Paternalism of Partnership. London: Zed Books

Chandler, D. 2010. International Statebuilding: The Rise of Post-Liberal Governance. New York: Routledge.

Cunliffe, P. 2010. "Critical Perspectives on R2P." Journal of Intervention and Statebuilding 4 (1): 35-37.

Doty, R. L. 1996. Imperial Encounters. Minneapolis: University of Minnesota Press

Ferguson, J. 1990. The Anti-Politics Machine. Minneapolis: University of Minnesota Press.

Ferguson, J. 2007. Global shadows: Africa in the Neo-Liberal World Order. Durham: Duke University Press

Gruffydd Jones, B. 2006. Decolonizing International Relations. Lanham: Rowman \& Littlefield.

Henderson, E. 2007. "Navigating the Muddy Waters of the Mainstream: The Mystification of Racism in International Relations." In African American Perspectives on Political Science, edited by W.C. Rich, 325-363. Philadelphia: Temple University.

Hintjens, H. 2014. "As if There Were Two Rwandas: Polarized Research Agendas on Post-genocide Rwanda." Chap. 9 in Conflict, Peace, Security and Development: Theories and Methodologies, edited by H. Hintjes and D. Zarkov. New York: Routledge.

Hobson, J.M. 2012. The Eurocentric Conception of World Politics. Western International Theory, 17602010. Cambridge: Cambridge University Press.

Kapoor, I. 2008. The Post-Colonial Politics of Development. New York: Routledge.

Mamadani, M. 2010. "Responsibility to protect or right to punish?" Journal of Intervention and Statebuilding 4 (1): 53-67.

Mignolo, W.D. and A. Escobar eds. 2010. Globalization and the Decolonial Option, New York: Routledge.

Muppidi, H. 2012. The Colonial Signs of International Relations. London: Hurst. 
Orchard, P. 2012. "The Evolution of the Responsibility to Protect: At a Crossroads?" International Affairs 88 (2): 377-386.

Rutazibwa, O. 2013. "What if We Took Autonomous Recovery Seriously? A Democratic Critique of Western Ethical Foreign Policy." Ethical Perspectives 20 (1): 81-108.

Sabaratnam, M. 2011. "IR in Dialogue but Can We Change the Subjects? A Typology of Decolonising Strategies for the Study of World Politics." Millennium Journal of International Studies 39 (3): $781-$ 803.

Scott, D. 1999. Refashioning Futures: Criticism After Postcoloniality. Princeton: Princeton University Press.

Seth, S. 2013. Postcolonial Theory and International Relations: A Critical Introduction. New York: Routledge.

Uwizeye, A., et al. Agaciro Documentary Film, 2011, 9:05 min., retrieved from https://www.youtube.com/watch?v=10BN_qmIQMU on June 22, 2014

Vitalis, R. 2000. "The Graceful and Generous Liberal Gesture: Making Racism Invisible in American International Relations" Millennium Journal of International Studies 29 (2): 331-356.

Wilson, W. 1917a. Address to the Senate on Peace without Victory. January 22, 1917. Retrieved from http://wwl2.dataformat.com/Document.aspx?doc=30688 on August 25, 2014.

Wilson, W. 1917b, Declaration of War Message to Congress. April 2, 1917. Retrieved from http://www.ourdocuments.gov/doc. php?flash=true\&doc=61\&page=transcript on August 25, 2014.

Wilson, W. 1919. Pueblo Speech. September 25, 1919. Retrieved from

http://voicesofdemocracy.umd.edu/wilson-the-pueblo-speech-speech-text/ on August 25, 2014.

\section{NOTES}

${ }^{1}$ Consider e.g. Wilson closing lines in his Address to the Senate on Peace Without Victory of January 22, 1917 where he states that: 'These are American principles, American policies. We could stand for no others. And they are also the principles and policies of forward looking men and women everywhere, of every modern nation, of every enlightened community. They are the principles of mankind and must prevail.'

${ }^{2}$ In the context of this essay, 'we' refers to the current dominant set of practices and ideologies originated in the West of which the author considers herself a part.

${ }^{3}$ This does not exclude the possibility of locating fundamental problematics in the content of the liberal Wilsonian triad of democracy, free trade and peace as we understand it today, but that is the object of a political or ideological discussion, that is ideally to be an integral part of a society's political life.

${ }^{4}$ See e.g. the introduction by P. Cunliffe of a special issue of this journal on R2P in 2010.

${ }^{5}$ For an excellent overview of the groundwork on decoloniality see e.g.: Mignolo, W.D. and A. Escobar, A. eds 2010. 
${ }^{6}$ Rwanda Days are government organised mass events in the Diaspora in which Rwandans and 'friends of Rwanda' abroad participate as well as a delegation of private businesses, civil servant, civil society and politicians from Rwanda come along.

${ }^{7}$ She recounted, laughing: "we would constantly say to each other "that is not Agaciro" when disagreeing or to tell each other off'

${ }^{8}$ One incident during this preliminary research trip illustrated the degree to which Agaciro as way of life has permeated society. My friend and I visited the newly opened library in Kigali and were directed by a security guard to leave our bags in a designated open storage area. She gave us each two numbers on small well-used white pieces of paper. One to put in our bags, one to keep on us. Upon exit we were to present the two pieces of paper before leaving the premises with our bags. My friend had lost the number she was supposed to keep on her, and a stern discussion in Kinyarwanda ensued between her and the security woman. At some point the word Agaciro fell and I asked my friend what that was about. She told me that she had suggested that it was just a stupid piece of white paper and that the library could simply copy the number for future visitors. The security guard had told her off saying that, even though that was indeed a possibility, that it was important to place value - i.e. Agaciro - even in the smallest of things, including a piece of paper. 